\title{
Superação da cegueira ideológica: do individual ao coletivo e do isolamento à abertura, partindo do processo como lócus de participação popular, segundo a principiologia constitucional
}

Overcoming of the ideological blindness: from individual to the collective and from the isolation to the opening, leaving from the process like lócus of popular participation, according to the constitutional set of principles

Patrícia Maino ${ }^{1}$

\begin{abstract}
Resumo
0 presente artigo pretende analisar a crise por qual passa a tarefa jurisdicional de resolução de conflitos e de realização dos direitos fundamentais em nosso ordenamento, propondo um resgate à participação social e principalmente à preocupação com o social, haja vista que, apesar do individualismo representar uma ideologia advinda dos primórdios, na atualidade, era denominada moderna, a essência individualista parece estar ainda mais aguçada, 0 que deve indubitavelmente ser revisto, uma vez que o futuro pressupõe prosperidade e não retrocesso.
\end{abstract}

Palavras Chave: Individual ismo; Coletividade; Jurisdição; Crise; Constituição.

\begin{abstract}
The present article intends to analyze the crisis by which goes the jurisdicional task of conflicts resolution and accomplishment of the fundamental rights in our system. It proposes a rescue to the social participation and mainly to the social care. Despite the individualism represents an ideology that becames of the origins, at the present time, it was denominated modern. The individualistic essence seems to be more sharpened, what undoubtedly should be reviewed, since it involves the futures prosperity and not backwards.
\end{abstract}

Keywords: Individualism; Collectivity; Jurisdiction; Crisis; Constitution.

\section{Introdução}

Ao intitular o presente artigo de "Superação da cegueira ideológica: Do individual ao coletivo e do isolamento à abertura, partindo do processo como lócus de participação

\footnotetext{
${ }^{1}$ Escrevente do Ofício de Notas da Comarca de Farroupilha/RS., Bacharel em Direito pela Universidade de Caxias do Sul - UCS. Endereço Comercial: Rua Cel. Pena de Moraes, № 228, sala 10, Farroupilha/RS., CEP: 95180-000. Endereço Eletrônico: patimaino@ hotmail.com.
} 
popular, segundo a principiologia constitucional", pretende-se tratar de um futuro relacionado à prosperidade e não ao retrocesso, sendo necessário, portanto, superar a cegueira ideológica ${ }^{2}$ e optar pela lucidez.

Nesse liame, inicialmente para se projetar o futuro é inevitável perpassarmos pelo passado e avaliar o presente, e principalmente para tratarmos da cegueira ideológica e a opção pela lucidez é indubitável a referência à discussão das causas e efeitos da crise por qual passa a tarefa jurisdicional de resolução de conflitos e de realização dos direitos fundamentais em nosso ordenamento, uma vez que demonstra talvez uma das maiores preocupações.

Sendo a jurisdição um dos principais instrumentos do Estado Democrático de Direito, essencial para a manutenção da estabilidade social e das instituições, revela-se importante identificar seus problemas e compreender as origens e os efeitos de sua crise. Os principais problemas enfrentados nesse cenário são a judicialização da política, a explosão da litigiosidade e o esvaziamento do espaço público e da democracia iniciado pelas crises da modernidade. 0 individualismo que resulta no paradigma hermenêutico liberalindividualista-normativista talvez seja o maior gerador dos problemas.

Um dos principais fenômenos observados hoje no seio da jurisdição é a judicialização da política apontada por Garapon (2001, p. 48), fato que fez com que o centro de gravidade das lutas políticas da democracia fosse transferido para o judiciário.

O fenômeno, observável nos países desenvolvidos e também no Brasil, é ocasionado por três causas inter-relacionadas: 1) a autonomização e o individualismo provocado pelo Estado-providência; 2) a crescente demanda de Estado, por meio da pressão

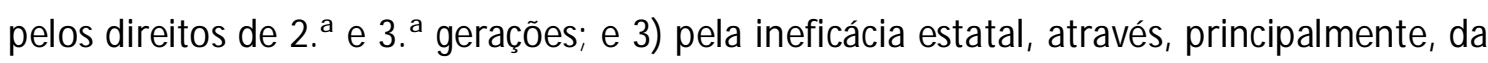
omissão dos seus poderes legislativo e executivo em tornar efetivos os direitos (SANTOS, 1997, p. 18).

Nesse cenário, primeiramente e principalmente, 0 individualismo radical, seguido da irresponsabilidade social e da crescente demanda por direitos, que também podem ser

\footnotetext{
${ }^{2}$ Denominação brilhante de SARAMAGO (in: SARAMAGO, José. Ensaio sobre a cegueira. São Paulo: Companhia das Letras, 2001; e SARAMAGO, José. Ensaio sobre a lucidez. 1. ed. São Paulo: Companhia das Letras, 2008.), trazida pela professora Doutora Jânia Maria Lopes Saldanha para no seminário intitulado "O futuro possível" Ponto 1. Jurisdição e constitucionalização do processo: a superação da cegueira ideológica e a opção pela lucidez, na disciplina Jurisdição e Processo no Programa de Pós Graduação Estrictu sensu de Direito da UNISINOS.
} 


\section{Superação da cegueira ideológica: do individual ao coletivo e do isolamento à abertura, partindo do processo como lócus de participação popular, segundo a principiologia constitucional}

conseqüência do primeiro, fizeram com que as lutas políticas fossem transferidas para 0 judiciário (GARAPON, 2001, p. 48), fenômeno esse denominado judicialização da política.

Algumas características da jurisdição, tais como neutralidade, imparcialidade e coercibilidade, são verdadeiros abrigos para os desafortunados da moderna sociedade (GARAPON, 2001, p. 44); o que intencionalmente seria uma instância de exceção (ou negativa) torna-se a regra, passando a tutelar a tudo e a todos.

Para Garapon (2001, p. 49) os efeitos deste fenômeno são funestos, sendo o mais grave o aprofundamento do esvaziamento do espaço público e da democracia iniciado pelas crises da modernidade..

Quanto à ineficácia do Estado brasileiro, pode-se dizer, em linhas gerais, que é, em boa medida, derivada dos equívocos das políticas públicas na realização da justiça social. Baseadas em uma estratégia de caráter redistributivo e assistencial, estas políticas erigiram imensos aparatos burocráticos gratuitos sob uma base político-estatal ainda clientelista e oligárquica, cujas promessas de justiça social desaguaram no mais puro assistencialismo populista e paternalista (FAUSTO, 2004, p. 61-63).

Em não realizando as "promessas da modernidade", como diz Streck, o Estado entitula-se o maior gerador de conflitos judiciais - a chamada explosão da litigiosidade. Parece que nossa realidade é mera encenação já que aparentemente estamos inseridos em um Estado democrático de direito, no entanto, a sociedade comporta-se como se fizesse parte de um Estado liberal e as crises são reflexo de um Estado social que nunca existiu (MACHADO; CATTONI DE OLIVEIRA, 2009).

A ineficiência estatal na concretização de direitos sociais traz o Estado como um dos principais geradores de conflitos judiciais.

A Jurisdição atua através do direito processual, em vista disso deve se questionar se essa estrutura, sistemática e/ ou funcionalidade processual é capaz de tratar dos problemas complexos da modernidade. E ainda, se está apto a tratar de tais problemas de forma compatível com a complexidade que apresentam e mais do que isso se essa forma viabiliza ao processo a participação popular indubitável ao Estado Democrático de Direito. Entre "crises da justiça e do processo", estão a morosidade, a inefetividade, o distanciamento da cidadania. A jurisdição deve concretizar e dotar os valores constitucionais de significado, devendo atuar por meio de um "processo jurisdicional formal e substancialmente vinculado 
aos princípios político-constitucionais" (M ACHADO; CATTONI DE OLIVEIRA, 2009, p. 118).

Sob essa ótica nos parece que a estrutura representa o principal obstáculo para a construção de um processo civil coletivo.

Observa com total propriedade Baptista da Silva ${ }^{3}$ que 0 direito e a jurisdição modernos têm cumprido satisfatoriamente suas funções, já que atendem aos interesses modernos para os quais foram criados. A crise situa-se no plano estrutural e está relacionada com 0 anacronismo entre este direito e sua respectiva jurisdição para com a realidade contemporânea, conforme adiante será visto. Ou seja, somente com a superação do paradigma racionalista, da estrutura, que o direito processual civil deixará de ser visto como mero procedimento, instrumento.

Destarte, é imprescindível tratar do paradigma liberal-individualista-normativista que persiste no seio de nossa cultura, e principalmente da necessidade de sua superação.

\section{Do individual ao coletivo e do isolamento à abertura: o processo como lócus de participação popular, a partir da principiologia constitucional}

0 viés individualista é a marca do pensamento ocidental, isso é fato.

Como não poderia deixar de ser, o perfil do processo de hoje é individualista, possui cariz iluminista e é reflexo das matrizes do pensamento de Guilherme de Ockan no século XIV (apud DUMONT, 2000). Os dois grandes movimentos espirituais que marcaram a derrocada do mundo medieval e o surgimento da modernidade - o Renascimento e seu mais significativo produto cultural, o humanismo, justificaram o individualismo.

Tais palavras caracterizam a sociedade moderna: individualismo, atomismo e secularismo (DUM ONT, 1993, p. 73).

Consoante os ensinamentos de Ovídio Araújo Batista da Silva (2004, p. 6), "a trilogia indivíduo, liberalismo e democracia são os pilares da cultura da modernidade".

A sociedade contemporânea apresenta-se extremamente complexa, pluralista e principalmente individualista, onde os objetivos pessoais se sobrepõem aos coletivos, trazendo ao sistema um confronto entre direitos tidos por fundamentais, e sob essa perspectiva deve-se encontrar um equilíbrio que tenha recepção constitucional.

\footnotetext{
${ }^{3}$ BAPTISTA DA SILVA, Ovídio Araújo, em palestra ministrada na aula da professora Jânia Maria Lopes Saldanha disciplina Jurisdição e Processo.
} 


\section{Superação da cegueira ideológica: do individual ao coletivo e do isolamento à abertura, partindo do processo como lócus de participação popular, segundo a principiologia constitucional}

Louis Dumont (1993) afirma que o individualismo, ocidental, teve origem no início da era cristã, e há quem defenda que perdure até os dias de hoje.

Charles Taylor (1997, p. 15) explica que, na modernidade, a "individualidade e 0 bem", ou a "identidade e a moralidade" são "entrelaçados", isso porque o individualismo sugere que somente é moral o que ele julga como sendo moral, ou, somente é bom algo que ele próprio considera ser bom. Ainda, o mesmo autor, conceitua agente humano, no Ocidente moderno, priorizando os "sentidos de interioridade, liberdade, individualidade e de estar mergulhado na natureza" (TAYLOR, 1997, p. 9), traços que se encaixam perfeitamente com o individualismo presente na fase inicial do Liberalismo.

Em vista do exposto, apesar de fazermos parte de uma sociedade ultra-moderna, ainda tem-se presente os conceitos individualistas de um liberalismo que não nos abandonou. Sob essa perspectiva para que se compreenda o processo como lócus de participação popular tem-se de partir do individualismo.

Dumont (1993, p. 36) afirma que "a religião foi o fermento essencial, primeiro, na generalização da forma e, em seguida, na sua evolução".

Thomas Hobbes a seu tempo já trazia o conflito indivíduo versus sociedade, explicando que o indivíduo em sua essência, natureza, opta pelo individualismo, pela soberania de seu "eu", no entanto, para perpetuar em seu movimento, que seria o seu ideal de felicidade, ele aceita pactuar, fazer parte do contrato "social", abdicando para tanto da plenitude de sua liberdade, harmonizando-se com os demais seres que formam a coletividade (HOBBES, 2008). "O homem é então capaz de alcançar a segurança, o conforto e o desenvolvimento de suas faculdades, mas ao preço da sujeição" (DUM ONT, 1993, p. 100).

0 individualismo faz com que seja rejeitada qualquer afirmação de humanidade que não advenha de sua própria interioridade (DUMONT, 1993, p. 94). Embora os liberais, semeadores do individualismo, pregassem maior autonomia individual justificando serem eles os titulares do poder ${ }^{4}, 0$ que de fato é verdadeiro, atribuíram a esse processo um viés extremamente individualista ao invés de social, o que resultou em maiores conflitos, haja vista que destinatária e titular do poder é a coletividade e não indivíduos isolados.

\footnotetext{
${ }^{4}$ Gilberto Bercovici ao longo de sua obra "Soberania e Constituição: Para uma Crítica do Constitucionalismo", assevera com muita propriedade que a nação é a titular soberana do poder, tudo deveria se remeter a ela, concretizando seus anseios. BERCOVICI, GILBERTO. Soberania e Constituição: Para uma Crítica do Constitucionalismo. Editora Quartier Latin do Brasil: São Paulo. 2008.
} 
Esse é o modelo reflexo do Estado liberal, criado para garantir o ideal liberal clássico de se evitar a interferência na esfera de liberdade do indivíduo e em suas relações privadas, assim referindo o mercado.

\section{Conseqüências e avanço do individualismo como resultado da cegueira ideológica}

0 fato é que a Constituição desde sua origem pretendia resolver questões fundamentais da sociedade civil e, concomitantemente, garantir a liberdade individual (TRIBE, 2007, p. 1), ou seja, já se deparava com o conflito sociedade versus indivíduo.

0 confronto entre interesses e principalmente entre direitos sempre traz complexidades, mas a colisão entre princípios igualmente essenciais e primordiais revelase ainda mais complexa. Sobretudo talvez a maior divergência seja o choque entre 0 individual e o coletivo.

A sociedade dita "pós-moderna", ainda sob os domínios do individualismo, em uma nação como a brasileira, onde os ideais de modernidade, o Welfare State ${ }^{5}$, o Estado do Bem Estar Social, não foram concretizados, ocasionou a ausência do elo de ligação entre o bem estar coletivo e os interesses individuais, o que faz com que ao invés de trabalharem juntos, colidam constantemente sob a busca de um mesmo ideal. 0 paradigma da igualdade formal e da autonomia da vontade pregada pelo Estado Liberal é inadmissível, exigindo que a sociedade, conjuntamente, trabalhe em vista do todo, sem deixar de preservar os direitos e garantias individuais, concretizando assim o Estado Democrático de Direito.

Para tornar efetivo o Estado Democrático, é indubitável que a Constituição se concretize, as relações de poder devem alcançar todos os indivíduos, no qual todas as regras e procedimentos estejam visíveis, para que deste modo alcancem a participação e interlocução com todos os interessados, inclusive pelas ações governamentais (LEAL, 2006, p. 27).

${ }^{5}$ Cf. MORAIS, José Luiz Bolzan de, em As crises do estado contemporâneo América latina:cidadania, desenvolvimento e estado. In: VENTURA, D. de F. de Lima (Org.) Porto Alegre:Livr. Adv., 1996, p. 88. Welfare State ou Estado de Bem-Estar Social "adjudica a idéia de uma comunidade solidária onde ao poder público cabe a tarefa de produzir a incorporação dos grupos sociais aos benefícios da sociedade contemporânea" vindo em contraponto ao modelo de Estado Liberal, onde o Estado representa apenas o papel de garantidor da paz social, onde a sociedade é composta de "indivíduos livres e iguais". 0 Estado passou a intervir na organização da vida econômica a fim de estabelecer um equilíbrio entre os particulares, buscando diminuir as desigualdades materiais existentes. Na Europa chegou-se a estabelecer o Welfare State ou Estado Providência, para os franceses, ou, ainda, Estado do Bem Estar Social, onde o Estado deixou sua condição passiva de "não fazer" e passou a ter uma atuação ativa na efetivação de uma justiça social. 


\section{Superação da cegueira ideológica: do individual ao coletivo e do isolamento à abertura, partindo do processo como lócus de participação popular, segundo a principiologia constitucional}

Verifica-se, desta forma, que o poder do Estado e o direito se tornam legítimos à medida que derivam de uma autoridade comum, sendo tal autoridade a supremacia popular, legitimamente representada, a qual, por sua vez, deve objetivar o bem da coletividade, descartando objetivos individuais, formando uma consciência coletiva, o que viabilizaria a convergência entre interesses públicos e privados, particulares e coletivos.

Laurence Tribe e Michael Dorf compreendem que a Constituição e o Estado em sua essência original possuem árduas tarefas, as de equilibrar direitos coletivos e individuais e a de constituir-se, no caso do Estado, de pessoas que devem governar outras pessoas.

Para formatar um governo no qual caberá a homens administrar outros homens, as grandes dificuldades serão: em primeiro lugar, capacitar o governo para controlar os governados; e em seguida o desafio será obrigá-lo a se autocontrolar. A dependência em relação às pessoas, é, sem dúvida, o principal controle sofrido pelo governo (TRIBE, 2007, p. 1);

Essa dependência em relação aos governados exerceria sim um controle aos administradores, no entanto para que efetivamente esse controle exista são imprescindíveis dois fatores, primeiramente a publicidade do poder possibilitando aos indivíduos visualisarem as ações governamentais e também é indispensável a fiscalização popular, que obviamente só ocorre quando o poder é visível.

Como visto, o progresso do individualismo é incontestável, Dumont (1993, p. 21) trata desse avanço com início no século XIII, por meio da emancipação da categoria denominada política e do nascimento da instituição denominada Estado. Trata ainda da emancipação da categoria econômica, a partir do século XVII, que também significa, no que diz respeito à religião, à política, à Igreja e ao Estado, um progresso do individualismo.

Consoante 0 mesmo autor, "A nação é precisamente o tipo de sociedade global correspondente ao reino do individualismo como valor" (DUM ONT, 1993, p. 21).

Ovídio Araújo Baptista da Silva (2004, p. 304) sabiamente afirma que "Considere-se que 0 Direito, no modo como o concebe o pensamento moderno, pensado como 0 predomínio da vontade de alguém sobre a vontade de outrem - o direito como relação interpessoal do poder-, traz em si o germe do conflito, o sinal inconfundível do individualismo". 
O capitalismo, segundo o entendimento de Ovídio, é o pilar de toda essa cultura individualista: "O capitalismo tornou possível a redefinição da democracia e sua redução ao liberalismo" (BAPTISTA DA SILVA, 2004, p. 317).

É nestas condições que Ovídio Araújo Batista da Silva (2004, p. 304-305) julga que o "nosso Direito é um produto da modernidade", e que a concepção jurídica moderna colabora com o individualismo, atribuindo também à democracia o progresso do pensamento moderno:

A concepção jurídica moderna opõem-se ao comunitário, tanto da filosofia clássica quanto da estrutura social da Idade Média. Por sua vez, também a democracia caracteriza-se por ser um regime político que, não apenas pressupõe o conflito, como o tem como uma de suas virtudes naturais. É o conflito que gera a competição, matéria prima do progresso e do desenvolvimento, as ideologias básicas do pensamento moderno (BAPTISTA DA SILVA, 2004, p. 304-305).

Norberto Bobbio (2000, p. 34), convergindo no sentido, afirma que a democracia "nasceu de uma concepção individualista da sociedade".

Nas palavras de Ovídio Araújo Batista da Silva (2004, p. 38) "Os grupos e não os indivíduos são os protagonistas da vida política numa sociedade democrática, na qual não existe mais um soberano, o povo ou a nação". E o alarmante é que não apenas os indivíduos ajam de forma egoísta vislumbrando apenas o seu benefício, o que se revela ainda mais problemático é que as instituições, o Estado sustentam ser o indivíduo o destinatário do poder, na realidade, nem mesmo sabem, nas palavras de Ovídio, "o que seja autonomia política" (BAPTISTA DA SILVA, 2004, p. 309).

A questão primordial se refere ao que está por vir, tendo em vista que 0 individualismo marcou o passado, está inserido em nosso presente e está projetado para o futuro, Ovídio Araújo Batista da Silva (2004, p. 306) reflete a respeito "O individualismo, não apenas está inscrito no cerne das instituições modernas, como se amplia e reforça na medida que os sistemas sociais contemporâneos desenvolvem-se, seguindo uma lógica imanente". De todo modo Ovídio revela-se um otimista, crê que seja possível "domar" o capitalismo, e realizar transformações que desencadeiem em uma "autêntica democracia", para tanto a "compatibilidade entre individualismo e democracia" revela-se crucial, e o que de forma alguma pode ocorrer é a superação do cidadão pelo indivíduo (BAPTISTA DA SILVA, 2004, p. 306). 


\section{Superação da cegueira ideológica: do individual ao coletivo e do isolamento à abertura, partindo do processo como lócus de participação popular, segundo a principiologia constitucional}

Para Hannah Arendt (2001), houve a perda da distinção entre as esferas pública e privada, todavia, sob uma concepção mais realista e infelizmente pessimista, o que parece é que tudo foi individualizado. A modernidade, que em tese, deveria abdicar do ideal individualista do liberalismo, parece expandir essa ideologia.

O capitalismo, de fato, também contribuiu e muito para a ploriferação do individualismo, fazendo com que o privado passe a ter supremacia e invadir o domínio público.

Gisele Cittadino (2004, p. 14) afirma que o pensamento jurídico brasileiro é marcadamente positivista e comprometido com a defesa privada dos cidadãos. Está comprometidamente ligada ao liberalismo, onde se busca mais a implementação de direitos civis e políticos do que sociais, muito mais da democracia representativa do que participativa.

Os representantes do constitucionalismo "comunitário" são contrários à Constituição defensora de autonomias dos indivíduos (fechada), mas sim enfatiza os valores do ambiente sociocultural da comunidade, opõe uma idéia de constituição aberta, uma constituição com conteúdos tanto normativos (direito comunitário), como extranormativos (usos e costumes) e metanormativos (valores e postulados morais), ultrapassando a concepção de direitos subjetivos para dar lugar às liberdades positivas. Adotam, então, a expressão direitos fundamentais do homem, que designa, no nível do direito positivo, as prerrogativas e instituição que ele concretiza em garantias de uma convivência digna, livre e igual para todos. Para José Afonso da Silva, os direitos fundamentais do homem "são direitos que nascem e se fundamentam, portanto, no princípio da soberania humana" (CITTADINO, 2004, p. 16-18).

Os direitos fundamentais nascem, primeiramente, como valores reconhecidos pela comunidade, e, como tais ingressam no texto constitucional, constituem-se em núcleo básico de todo o ordenamento constitucional, servindo de metas e objetivos a serem alcançados pelo Estado Democrático de Direito.

Em outras palavras, a abertura constitucional permite que cidadãos, partidos políticos, associações, etc. integrem o círculo de intérpretes da constituição, democratizando o processo interpretativo - na medida em que ele se torna aberto e público - e, ao mesmo tempo, concretizando a constituição - lê-se, efetivar o sistema de direitos constitucio nalmente assegurados (CITTADINO, 2004, p. 18-19). 
Cittadino idealiza a promulgação da Constituição Cidadã, pois em sua visão, é a expressão definitiva deste movimento de retorno ao direito. Trata-se de pretensão de reencantar o mundo. "Seja pela adoção do relativismo ético na busca do fundamento da ordem jurídica, seja pela defesa intransigente da efetivação do sistema de direitos e do papel do judiciário" pretendendo se resgatar a força do direito. Os encarregados disto são os Constitucionalistas "comunitários" (CITTADINO, 2004, p. 14).

Novamente, conclui-se, pela exposição da mesma autora, que a sociedade, a vida pública e até mesmo o Estado, não podem ser vistos sob uma perspectiva privada e individualista, é esse o principal dogma a ser combatido, 0 individualismo exacerbado, tanto no que se refere à Nação, quanto no que se refere aos seus representantes.

Quanto à perspectiva individualista e no que se refere às conseqüências dessa postura, é relevante trazer o seguinte julgado que retrata uma realidade por tantas vezes presenciada cotidianamente:

ção de Suspensão de Segurança $3263^{6}$ - Concessão de Medicamentos, onde relata que a M inistra Ellen Gracie, presidente do Supremo Tribunal Federal, deferiu a Suspensão da Segurança (SS) 3263. desobrigando o Estado de Goiás de fornecer gratuitamente medicamentos Synarel, Gonal e Ovidrel para uma paciente portadora de infertilidade feminina. O Procurador Geral Goiano afirma que esses medicamentos não constam na lista dos remédios de alto custo financeiro que o Estado forneceria gratuitamente, portaria 2577/2006 do Ministério da Saúde, e afirma ainda que a enfermidade - infertilidade feminina associada à inovulação - não é capaz de causar risco à vida, e concluiu dizendo que o fornecimento desses medicamentos traria grave lesão à ordem, à saúde à economia pública, pedindo a suspensão da liminar e a extensão desses efeitos "a todas as decisões semelhantes, desde que ainda não tenham transitado em julgado, como forma de respeito ao princípio da economia processual".

Embora a Ministra tenha deferido a Suspensão da Segurança e desobrigado 0 Estado de Goiás a fornecer tais medicamentos gratuitamente, ela negou o pedido do Estado Goiano em estender os efeitos dessa decisão a outros casos semelhantes, já que julgou ter sido incabível tal pedido em vista de que "não há que se falar em suspensão genérica de decisões".

\footnotetext{
${ }^{6}$ Disponível em: (HTTP:// www.stf.jus.br/portal/processo/verProcessoTexto.asp?id=2150129\&tipoApp=RTF).
} 


\section{Superação da cegueira ideológica: do individual ao coletivo e do isolamento à abertura, partindo do processo como lócus de participação popular, segundo a principiologia constitucional}

O caso citado relata uma típica demanda individualista, que é tão freqüente e sobrecarrega o Poder Judiciário trazendo inúmeras conseqüências negativas, tendo em vista que, por mais que seja louvável a solicitação de medicamentos para infertilidade feminina, e sabendo que para aquela pleiteante esse pedido possa representar um direito fundamental em sua vida, há de se ter em mente um Estado debilitado como o Brasileiro, não sendo possível negar essa realidade, realidade tal que deixa doentes morrerem em filas de hospitais por falta de atendimento e medicamentos pelo fato de não haver orçamento suficiente para custear a saúde pública e todas as suas súplicas. Em vista disso, há de se consensar que em não havendo orçamento para custear doenças com risco à vida, não são cabíveis demandas à medicamentos que não servirão para curar um doente em estado fatal, isso representa uma demanda individual, pois se todos os cidadãos decidirem pleitear em juízo que o Estado arque com todas as necessidades, que para cada um em sua individualidade, representa o Direito maior em sua vida, então ter-se-á o caos.

Obviamente tem de ser criadas Políticas Públicas que abranjam tais questões, num Estado Democrático de Direito todas as necessidades fundamentais e básicas deveriam ser supridas, no entanto é incoerente a perpetuação da cegueira objetivando somente interesses privados, individuais e egoístas.

\section{Da cegueira à visibilidade sob uma perspectiva coletiva, constitucional, participativa e global}

Na visão de Otfried Höffe (2005, p. 6), as complexidades de hoje tem proporções globais, "novos atores ganham poder e influência no cenário mundial", "regras coletivas e poderes públicos substituem a arbitrariedade e o poder provado", sendo necessário que poderes públicos sejam instituídos e organizados democraticamente (HÖFFE, 2005, p. 20). Nessas condições, a opinião pública, que representaria o desapego ao individualismo em prol de um bem comum a toda a coletividade, é o cerne da discussão, já que ela representa muito mais do que um simples "canal de indignação, mas para que a opinião pública possa exercer a sua primordial função fiscalizadora e crítica, necessita de uma política visível, efetivamente pública, onde os cidadãos tenham direito à voz e voto. E ainda, afirma Höffe (2005, p. 376), em uma Democracia Representativa, todos, administradores e Estado em 
geral, devem responder à opinião pública constantemente e não somente em épocas eleitoreiras.

Destarte, devem ser imediatas as providências a serem tomadas diante desta considerada cegueira para com a realidade social e a Constituição, de explosão de litígios e de ineficácia de soluções apontadas pelas decisões jurídicas, a segmentação social se reforça e a possibilidade de consenso é pulverizada; coloca-se a perder o sentido do próprio contrato realizado em 1988, um dos poucos repositórios de acordo em uma sociedade estratificada como a nossa, ao que se abrem precedentes para a possibilidade de contestação da própria democracia.

Para tanto, a participação popular exerce fundamental e primordial papel no resgate à democracia, uma vez que, a sociedade encontra-se carente de instrumentos de participação e reivindicação social, seja política ou judicial. No Brasil, os altos índices de analfabetismo e a baixa renda não permitem ao cidadão sequer reconhecer direitos, quanto mais procurar o judiciário para reivindicá-los (CAPPELLETTI, 1988, p. 21-24).

O princípio constitucional do acesso à Justiça se, por um lado, deve ser louvado, por outro criou expectativas irreais acerca das reais possibilidades de o Poder Judiciário solucionar os conflitos. Todavia se esse princípio constitucional abdicasse da cultura individualista dos institutos processuais, somada à desburocratização do próprio Poder Judiciário, seria viabilizada a participação popular tão necessária à nação brasileira.

Cittadino (2004, p. 19-21) propõe a “criação, pelo próprio ordenamento constitucional, de uma série de instrumentos processuais-procedimentais que, utilizados pelo círculo de intérpretes da constituição, possa vir a garantir a efetividade" daqueles direitos. Para isto, deve haver o privilégio à prestações positivas do Estado (dever de ação) do que procedimentos negativos (dever de abstenção). Como exemplo deste exercício aparece 0 direito ao voto onde mesmo na ausência da intervenção legislativa ele pode ser gozado. Ao contrário tem-se nos chamados direitos econômicos e sociais, onde, sem a atuação do legislativo, não há como garantir-Ihes eficácia.

É precisamente contra este "não-fazer" que o constitucionalismo "comunitário" erige determinados instrumentos processuais - mandado de injunção e ação de inconstitucionalidade por omissão - para a efetivação da Constituição. 0 dever de ação associa-se, diretamente, ao controle da omissão. Aqui o papel judiciário tem papel 


\section{Superação da cegueira ideológica: do individual ao coletivo e do isolamento à abertura, partindo do processo como lócus de participação popular, segundo a principiologia constitucional}

proeminente, pois é o último intérprete da Constituição. "Não seria exagero afirmar que o constitucionalismo 'comunitário' brasileiro defende a figura de um Estado-Juiz, acompanhando, também aqui, o pensamento comunitário na defesa da jurisdição constitucional enquanto regente republicano das liberdades positivas" (CITTADINO, 2004, p. 21-22).

Para Peter Haberle (apud CITTADINO, 2004, p. 30-31) deve-se formular o conceito de "constituição aberta", defendendo o círculo de intérpretes, pela via do processo aberto e público (democracia). "Dos cidadãos aos partidos políticos, passando por sindicatos e órgãos estatais, todos tomam parte do processo de interpretação da constituição. Sem a participação de todas as forças da comunidade política, não há como concretizar a constituição" (CITTADINO, 2004, p. 30-31).

Consoante Gisele Cittadino (2004, p. 63-64) a realização dos valores constitucionais vai depender de uma comunidade de intérpretes e mecanismos processuais, além de uma hermenêutica constitucional que ultrapasse o formalismo positivista.

Na concepção de Otfried Höffe (2005, p. 376), a representatividade democrática efetivada através da participação popular é inquestionável, se faz mister que todo cidadão tenha direito a voz e voto, devendo a política ser exercida pelo povo inteiro, e para tanto devem haver permanentes pesquisas de opinião pública. "Para uma democracia participativa, a opinião pública é uma instância crítica, perante a qual deverão responder a Política inteira - e não apenas o Governo -, e também o Parlamento, o Judiciário e inclusive o Tribunal Constitucional" (HÖFFE, 2005, p. 376).

Para muitos doutrinadores, a ordem jurídica brasileira não é carente de instrumentos normativos para operacionalização da participação popular na administração pública. Mas a participação permanece escassa. Falta uma clara percepção de suas dimensões não normativas e a exploração mais atenta das normas existentes. A participação popular na administração pública é conceito necessariamente mais restrito: trata-se da interferência no processo de realização da função administrativa do Estado, implementada em favor de interesses da coletividade, por cidadão nacional ou representante de grupos sociais nacionais, estes últimos se e enquanto legitimados a agir em nome coletivo.

Reconheçamos que o brasileiro pobre só vem a conhecer os fóruns por meio da justiça penal, quando geralmente se apresenta patente a ineficácia da assistência judiciária 
em promover a defesa do acusado (ADORNO, 1994).

Talvez a democratização radical possa fazer o Poder Judiciário mais próximo da cidadania.

É indiscutível, portanto, a participação democrática e direta da cidadania no processo, uma das formas, e talvez a maior delas, seria a audiência pública, através de sessões de discussão, aberta ao público, sobre tema ainda passível de decisão.

$\mathrm{Na}$ esfera do poder legislativo identifica-se o plebiscito, o referendo, e a iniciativa popular das leis como algum dos mecanismos de participação popular. No Judiciário, o exercício da ação popular constitucional e as ações coletivas em geral. E neste sentido, o instituto da audiência pública, vem ganhando projeção no cenário jurídico e político nacional como mecanismo de participação no processo decisório, embora também seja previsto no curso do processo legislativo. ${ }^{7}$

Num Estado Democrático de Direito deve haver a consulta pública, o constante retorno à vontade popular, o respeito à opinião da coletividade, que é a real titular do poder, nessas condições a audiência pública é o instituto que mais se destaca. A audiência pública é uma reunião aberta em que a autoridade responsável colhe da comunidade envolvida suas impressões e demandas a respeito de um tema que será objeto de uma decisão administrativa, ou seja, conscientiza o cidadão dos problemas comunitários, e em havendo essa discussão pública forma-se a própria opinião pública que pode e deve ser observada pelos administradores. Em contrapartida, na democracia representativa as audiências públicas são relativas, na medida em que os juizes elegem os participantes. Uma opção seria o alargamento da Democracia.

Além da participação popular, outro ponto a ser discutido e talvez projetado para um futuro não tão distante, diz respeito a questões de ordem internacional, Otfried Höffe (2005, p. 18-19) expressando preocupação global, mundial, que se contrapõe às várias faces do individualismo, no sentido de superioridade aos interesses coletivos e principalmente mundiais, que em sua visão representariam parte do todo, propõe uma República Mundial, ou um Estado mundial, por entender que certas questões referentes a valores essenciais não podem ser discutidas isoladamente uma vez que dizem respeito a toda a humanidade:

\footnotetext{
${ }^{7}$ http:// www .direitodoestado.com/revista/REDAE-13-FEVEREIRO-2008-ANTONIO\%20CABRAL.pdf.
} 


\section{Superação da cegueira ideológica: do individual ao coletivo e do isolamento à abertura, partindo do processo como lócus de participação popular, segundo a principiologia constitucional}

Quem deve assumir as competências referentes ao direito de autodeterminação dos povos, a um eventual direito de secessão e às violações maciças de direitos humanos que exigem uma intervenção humanitária? Será que se trata de assuntos de alçada inteiramente interna de cada Estado, a ponto de a República Mundial não pode interferir, ou seriam apenas assuntos relativamente internos ou talvez até mesmo apenas supostamente internos, de forma que a República Mundial poderia assumir a Responsabilidade? (HÖFFE, 2005, p. 445)

Todavia, ele próprio pondera que "enquanto não houver uma opinião pública mundial funcionando regulamente, a instauração de uma República Mundial subsidiária e federal será irresponsável" (HÖFFE, 2005, p. 379). É necessária, para tanto, além de uma opinião pública mundial, a existência de uma consciência cívica mundial.

0 autor refere que "a opinião pública mundial já registra um desenvolvimento relativamente grande. É o caso dos direitos humanos" (HÖFFE, 2005, p. 378).

"A consciência mundial, por seu turno, é uma pré-condição para eventuais plebiscitos globais" (HÖFFE, 2005, p. 379).

De toda forma, há de se ter em mente que as grandes potências dominantes tornarse-ão ainda maiores com o processo de internacionalização já que estes sempre serão portavozes de determinados interesses, como é o caso dos soberanos, das instituições financeiras internacionais. Afinal, não passa de ficção a idéia de que são capazes de representar a soma dos interesses (HOBBES, 2002, p. 131) ou a encarnação da vontade geral (ROUSSEAU, 1995, p. 33).

Hoffe (2005, p. 379), nesse sentido:

De resto, aqui também deverá impor resistência ao perigo de uma presença majoritária de alguns Estados de grande porte. Para que os interesses de todos os outros países não sejam esmagados por aqueles defendidos por uns seis ou oito países mais populosos, recomenda-se a 'maioria dupla' usada na Suíça: no caso de plebiscitos globais, teriam de ser consideradas tanto a maioria dos países quanto a maioria da população mundial.

No mesmo sentido Marcelo Neves (1994, p. 149) afirma que:

.(...) A bifurcação no desenvolvimento da sociedade moderna (mundial) resultou, para os países periféricos, numa crescente e veloz complexidade social, sem que daí surgissem sistemas sociais capazes de estruturar ou determinar adequadamente a emergente complexidade.

Revista de Direito Público, Londrina, v, 4, N. 2, P. 215-233, m AIO/AGo. 2009. 
Portanto é necessário estar atento ao que há por trás da Universalização do processo mundial, ou seja, uma lógica dominante, uma vez que, não há justiça global sem justiça cognitiva global.

\section{Conclusão}

Faz-se imprescindível citar o ilustre estudioso Ovídio Araújo Batista da Silva (2004, p. 9) quando reflete quanto aos nossos reais anseios: "uma jurisdição compatível com nosso tempo, uma jurisdição capaz de lidar com a sociedade de consumo, complexa e pluralista, em seu estágio de "globalização', e acrescente-se, um sistema capaz de contornar a sociedade ainda enraizada pelo individualismo.

Diante do exposto, observa-se que para que de fato concretizemos o Estado Democrático de Direito, tem-se de deixar as concepções individualistas e refletir sobre a idéia de coletividade respeitando os ideais propostos pela Constituição, abdicando de interpretações e leituras subjetivas. Laurence Tribe e Michael Dorf (2007, p. 12)trazem a idéia de que a Constituição não é simplesmente o que queremos que ela seja, e propõem que "Temos que encontrar princípios de interpretação que possam ancorar a Constituição em uma realidade externa mais segura e determinada. E essa tarefa não é simples. Um problema básico é que o texto deixa em si mesmo um espaço grande demais para 0 exercício da imaginação" (TRIBE; DORF, 2007, p. 13). Ou seja, dá margem à discricionariedade que por vezes resulta em arbitrariedade.

É inquestionável o individualismo que ainda assombra a atualidade, e que a nação é constituída por indivíduos que visam seus exclusivos interesses, sobretudo a de se convir que "Da vontade individual de todos surge uma vontade geral" (DUM ONT, 1993, p. 104), e que esta vontade geral é a soberana, e portanto, transcende à vontade individual.

natural que diante da pluralidade de atores e interesses, sejam trazidos à tona conflitos de ordem individual e coletiva, trazendo por conseqüência o confronto entre direitos em dadas situações, na própria preservação da vida humana são identificadas restrições à liberdade, no momento em que é vedada a auto-moléstica. Nesse sentido, a pergunta sugerida por Dorf e Tribe (2007, p. 85) é "como a Constituição pode canalizar as escolhas dos valores?" E a questão primordial revela-se como deve ser a decisão diante desses confrontos. 


\section{Superação da cegueira ideológica: do individual ao coletivo e do isolamento à abertura, partindo do processo como lócus de participação popular, segundo a principiologia constitucional}

Em vista da coletividade e no desprezo a decisões subjetivas, há de se formar argumentos constitucionais, critérios que possuam abrangência global.

A repugnância a conceitos universalizantes é cotidianamente constatada, Laurence Tribe e M ichael Dorf (2007, p. 18) afirmam que “Grande parte das pessoas já perdeu a fé nas idéias de eterno, universal e verdade inquestionável. M as de alguma forma, na sua maneira comum de viver, ainda conseguem distinguir entre o que parece um argumento bom e o que parece sofisma". E conclui que "é importante apresentar argumentos significativos em um mundo bombardeado com verdades de última hora" (TRIBE; DORF, 2007, p. 19).

De toda forma é imprescindível se ter argumentos constitucionais. Buscar respostas constitucionalmente adequadas significa, nas palavras de Tribe e Dorf (2007, p. 19): "focar nossa energia interpretativa nos aspectos concretos da Constituição. Para começar a fazer a distinção entre as formas boas e as formas ruins de criar argumentos sobre o que a Constituição significa".

É necessário que haja uma inclusão na esfera dos direitos sociais, uma reconstrução de valores coletivos, em detrimento do egoísmo e do individualismo atomista.

A constituição é a soberana, e a mesma prevê tanto os direitos coletivos quantos os fundamentais individuais, que são igualmente relevantes, no entanto, para que se tenha a efetivação de todos esses direitos há de se superar essa visão unilateral, individual, ou nos dizeres da professora Jânia M aria Lopes Saldanha, há de se superar a própria cegueira, pois preservando e contribuindo à concretização de direitos coletivos estar-se-á garantindo o cumprimento de todos direitos fundamentais.

Todavia é árdua essa tarefa, já que a cultura individualista ainda permanece enraizada em nosso contexto, e, sobretudo, aplicar a Constituição não tem um entendimento único, nem preciso, embora se produzam inúmeras teorias que visam uma consistente teoria constitucional, Tribe e Dorf entendem que "não é possível alcançar a definição da última palavra da essência da Constituição; quando isso se torna possível, a Constituição acaba de perder sua relevância perante uma sociedade em constante mudança" (2007, p. 35). E concluem que "não existe fórmula capaz de eliminar definitivamente a necessidade de escolhas judiciais" (TRIBE; DORF, 2007, p. 37), e afirmam que: 
Finalmente, a experiência norte-americana ensina que a melhor forma de adquirir 'expertise' em interpretação constitucional é sujeitar todos os argumentos constitucionais e decisões à constante análise e à crítica contínua, tanto do âmbito dos termos quanto do âmbito das nossas tradições para construí-los (TRIBE; DORF, 2007, p. 37).

Ou seja o texto constitucional deve ser interpretado, discutido, analisado a todo 0 momento, não resultando em um modelo único e perfeito, frente as pluralidades e multiplicidades a que está disposta a Constituição.

Resta, portanto claro que é extremamente difícil, frente a contextos históricos, sociais e culturais divergentes, e à subjetividade que tudo isso envolve, prolatar uma decisão, única, consistente e principalmente justa. A democracia pressupõe a defesa da diversidade, do pluralismo e a conjugação entre as esferas pública e privada, oportunizando a participação popular, e todos esses aspectos se opõem ao individualismo. Portanto, (re)construir uma cultura coletiva, a crença nos valores públicos, abrir espaço à representatividade adequada da sociedade no processo, abdicando de concepções unicamente individuais que viciaram o processo civil e todo o sistema, representa uma importante iniciativa para um futuro melhor.

\section{Referências}

ARENDT, Hannah. A condição humana. 10̣ Ed. Rio de Janeiro: Forense Universitária, 2001.

BAPTISTA DA SILVA, Ovídio Araújo. Processo e Ideologia: 0 Paradigma Racionalista. Rio de Janeiro: Forense, 2004.

BERCOVICl, GILBERTO. Soberania e Constituição: Para uma Crítica do Constitucionalismo. Editora Quartier Latin do Brasil: São Paulo. 2008.

BOBBIO, Norberto. O Futuro da Democracia. Uma defesa das regras do jogo. 7a Ed. São Paulo, Editora Paz e Terra, 2000.

BOLZAN DE M ORAIS, José Luis. SALDANHA, Jânia M aria Lopes. ESPINDOLA, Angela Araujo da Silveira. Jurisdição constitucional e participação cidadã. Por um processo formal e substancialmente vinculado aos princípios político-constitucionais. In: MACHADO, Felipe Daniel Amorin; CATTONI DE OLIVEIRA, Marcelo. Constituição e processo: a contribuição do processo ao constitucionalismo democrático brasileiro. Belo Horizonte: Del Rey, 2009. 
CAPPELLETTI, Mauro. Acesso à Justiça. Tradução de Ellen Gracie Northfleet. Porto Alegre: Fabris, 1988.

CITTADINO, Gisele. Pluralismo, Direito e Justiça Distributiva. Elementos da Filosofia Constitucional Contemporânea. 3. Ed. Rio de Janeiro: Editora Lúmen Juris, 2004. 